Кривий Ріг : Книжкове видавництво Кирєєвського, 2009. - 316 с. 7. Стрюк А. Н. Современные подходы к проектированию и реализации комбинированного обучения / А. Н. Стрюк // Информатизация образования - 2012: педагогические основы разработки и использования электронных образовательных ресурсов : материалы Международной научной конференции, Минск, 24-27 октября 2012 г. / редкол. : В. В. Казаченок (отв. ред.) [и др.]. - Минск : БГУ, 2012.- С. 379-383.

$$
\text { УДК } 37.014 .54+378.147: 331.5
$$

Тетяна Ящук

\title{
РИНОК ОСВІТНІХ ПОСЛУГ І РИНОК ПРАЦІ: ПРОБЛЕМИ ВЗАЕМОДІЇ
}

\section{Ящук Т. А. Ринок освітніх послуг і ринок праці: проблеми взаємодії.}

У статті розглянуто механізм взаємодії замовників і споживачів на ринку освітніх послуг. Виявлено інструменти економічного механізму управління якістю освітніх послуг та структура підготовки кадрів у галузі знань, потреби підприємств. Указано на наявність дисбалансу між попитом і пропонуванням спеціалістів на ринку. Обгрунтована необхідність регулювання взаємодії ринків освітніх послуг і праці. Запропоновані ідеї щодо вдосконалення економічного механізму управління якістю.

Ключові слова: ринок освітніх послуг, ринок праці, освітня послуга.

Ящук Т. А. Рынок образовательных услуг и рынок труда: проблемы взаимодействия.

В статье рассмотрен механизм взаимодействия заказчиков и потребителей на рынке образовательных услуг. Определены инструменты экономического механизма управления качеством образовательных услуг, а также показаны структура подготовки кадров по отраслям знаний, потребности предприятий. Определен дисбаланс между спросом и предложением специалистов на рынке. Обоснована необходимость регулирования взаимодействия рынков образовательных услуг и труда, предложены направления совершенствования экономического механизма управления качеством.

Ключевые слова: рынок образовательных услуг, рынок труда, образовательная услуга.

Yashchuk T. A. Educational services market and labor market: problem of interaction.

Interaction mechanism of clients and users on educational services market is observe in the article. Tools of economic management mechanism of quality educational services and training structure in the field of knowledge and needs of enterprises are examined.

The imbalance between demand and supply of specialists in the market is shown. The discrepancy between labour market demand for specialists with higher education and their training volume is a global problem of modern economic and political system of our country. The introduction of new educational technologies, immersion in approaches of the European education by the national high school is an oriented point for youth, but not on filling of the real highly paid vacant areas of modern labour market. The most important indicator of competitive specialist is the development and improvent of labour quality, and high qualification of workers, who master the latest technology, and are able to work with modern equipment.

The necessity for cooperation between the education market and labour is shown in the article. To eliminate the negative interaction it is necessary to provide the interaction between the labour market and the education market by studying their condition and the development of shortterm forecasts of employment opportunities. To solve this problem it is necessary to activate participation of higher education institutions in addressing the problem of overcoming the imbalance of education market and the labour market, providing the economy of the country with highly skilled labour force. An international experience shows that marketing services of higher education institutions that study the needs of the labour market, requirements of employers must become an integral part of the management structure of higher education institution.

Key words: educational services market, labour market, educational service. 
Підвищення вимог до якості робочої сили та їі конкурентоспроможності напряму залежить від професійно-кваліфікаційного дисбалансу попиту і пропозиції робочої сили, якими нині характеризується національний ринок праці в Україні. Крім того, не завжди рівень підготовки випускників навчальних закладів різних рівнів акредитації відповідає новим вимогам роботодавців.

У зв'язку з цим виникає проблема працевлаштування молоді та надання їй першого робочого місця. За цих обставин особливої актуальності набуває посилення взаємодії та взаємозв'язку між ринком праці та ринком освітніх послуг і залучення вищих навчальних закладів до розв’язання проблеми зайнятості своїх випускників [5].

Актуальні наукові дослідження щодо сфери підготовки кадрів та взаємодії ринків освітніх послуг та праці наведені в працях таких вітчизняних науковців, як: Н. Анішина, О. Балакірева, С. Бандур, І. Гнибіденко, А. Колот, Е. Лібанова, О. Новікова.

Метою статті є теоретичне обгрунтування необхідності регулювання взаємодії ринків освітніх послуг; пошук шляхів підвищення ефективності взаємодії та взаємозв'язку ринків праці й освітніх послуг.

Сучасний розвиток економіки України, як і багатьох країн, що здійснили перехід до нової моделі соціально-економічної системи, відзначається небувалою швидкістю змін. Ринкові перетворення та структурні трансформації економіки цілком закономірно викликають переорієнтацію економічних запитів суб'єктів господарювання і змінюють структуру попиту на працю. Україна, прагнучи віднайти i зайняти своє місце в європейському освітньому просторі, й особливо, після підписання Болонської декларації, постала перед проблемою зміни як інституціональних форм надання освітніх послуг, так i самих підходів до організації вищої освіти. Тому останні роки для вітчизняної системи освіти стали перманентним процесом іiі реформування, який, власне, не завершено i донині [5].

Ідеальна модель, якої прагнули реформатори, передбачала трансформацію університетів в освітні організації принципово нового типу, які були б зорієнтовані на глобальний ринок освіти і технологічних інновацій. Однак, на практиці просування до описаної моделі виявилося досить суперечливим і неоднозначним процесом. Передусім все, прагнучи досягнення певного рівня системної конвергенції української освіти в глобальний освітній простір, у країні було сформовано стандарти, які мали відповідати рівню світового ринку, а не національного. Їх упровадження у вітчизняний освітній процес відразу висунуло на передній план проблему відсутності взаємозв'язку між вищою освітою й розвитком реальної економіки. У переважній своїй більшості галузева структура України відповідає індустріальній стадії розвитку і ще надто далека від рівня розвитку країн, які успішно завершують перехід до постіндустріального суспільства. Тому знання, які отримують нині українські студенти, виявляються не затребуваними в умовах вітчизняної практики [4].

Питанням розвитку освітніх послуг відповідно до вимог ринку праці останнім часом приділяється значна увага. Розрізненість інтересів бізнесу, змісту навчально-виховного процесу вищої школи та глобальних напрямків розвитку держави створює проблему ефективного функціонування механізму кадрового забезпечення економіки. Це призводить до відокремлення ринку освітніх послуг від ринку праці: підготовка вищою школою кадрів орієнтується на запити абітурієнтів і їх батьків, а не на сучасні економічні процеси і вимоги роботодавців.

Популяризація високих щаблів у рейтингу популярності певних спеціальностей i подальша розбіжність із розподілом гарантованого працевлаштування призводить до того, що абітурієнти при виборі навчального закладу або певного фаху недостатньою мірою враховують чинник подальшого працевлаштування. Через відсутність науково обгрунтованих прогнозних оцінок потреб у фахівцях на ближню і дальню перспективу попит на фахівців конкретних спеціальностей є невизначеним. У цьому випадку з'являється ситуація незбалансованості попиту і пропозиції на ринку праці: надлишкова пропозиція одних професій та нестача інших [5]. 
Ринок освітніх послуг не може повністю задовольнити попит роботодавців та оперативно реагувати на зміни, що відбуваються на ринку праці. Звідси - різні оцінки якості підготовки в навчальних закладах, з одного боку, та роботодавців - 3 іншого [2]. Підвищення якості підготовки кваліфікованих фахівців промислової галузі має грунтуватися на формуванні дієвого механізму узгодженості визначення поточної потреби підприємств у кадрах відповідно до професій та спеціальностей.

У рамках реалізації плану заходів, вироблення нових підходів до встановлення механізму формування та розміщення державного замовлення на підготовку фахівців для всіх галузей економіки відповідно до поточних і перспективних потреб ринку праці Мінекономрозвитку розроблено Закон України «Про формування та розміщення державного замовлення на підготовку фахівців, наукових, науково-педагогічних та робітничих кадрів, підвищення кваліфікації та перепідготовку кадрів» від 20.11.2012 p. № 5499-VI [1]. Державне замовлення на підготовку фахівців, наукових, науково-педагогічних та робітничих кадрів, підвищення кваліфікації та перепідготовку кадрів (післядипломна освіта) формується 3 урахуванням середньострокового прогнозу потреби у фахівцях на ринку праці.

Особливості формування ринку знань визначаються також і його взаємодією з іншими ринками. Формування і функціонування ринку освітніх послуг підкоряється, звичайно, загальним законам ринкової економіки, проте володіє поряд специфічними особливостями. Погоджуючись із думкою науковця Т. Петрової, виокремимо такі: високий динамізм теоретичних i, особливо, практичних знань; територіальна сегментація і локальний характер; значна швидкість обороту знань, що диктується швидким науково-технічним прогресом; висока чутливість знань до ринкової кон'юнктури; індивідуальність їх виробництва; пропорційність державного втручання і їх регулювання; частота та сила обмеження на приватнопідприємницьку діяльність тощо [6].

Невідповідність між потребою ринку праці у фахівцях із вищою освітою і обсягами їх підготовки є глобальною проблемою сучасної економіко-політичної системи нашої держави. Упровадження нових освітніх технологій, занурення в підходи європейської освіти національною вищою школою, на жаль, є орієнтиром передусім на обгрунтований попит молоді на певні спеціальності, а не на заповнення реальних високооплачуваних вакантних напрямків сучасного ринку праці. Найважливішим показником конкурентоспроможності фахівця є формування і підвищення якості робочої сили, високої кваліфікації працівників, які володіють новітніми технологіями, знають сучасну техніку й обладнання.

Якість підготовки залежить від багатьох чинників. Це і стан навчальної бази, і професійний рівень викладача, і здібності та мотивація до опанування професійних навичок самого студента. Тому на державному рівні вкрай потрібно здійснити комплекс заходів щодо забезпечення економічних і соціальних гарантій діяльності педагогічних працівників, створення умов для підготовки фахівців відповідно до вимог ринку праці.

Безумовно, пріоритетною у відносинах на ринку праці є позиція роботодавців. Однак зараз більшість роботодавців розуміють ії дуже вузько, вважаючи, що майже всі випускники вищих навчальних закладів $\epsilon$ недостатньо кваліфікованими i не в змозі виконувати в повному обсязі на належному рівні поставлені виробничі завдання. Аргументом при цьому слугує недостатність у випускників практичних навичок, тим часом як самі роботодавці майже не вживають заходів для надання можливості проходження студентами вищих навчальних закладів виробничої практики, не дбають про співпрацю 3 навчальними закладами [6].

В економічній теорії визначено кілька моделей соціальної дискримінації на ринку праці. Одна із них - модель особистих упереджень Г. Беккера [2]. Ця модель подає макроекономічну інтерпретацію дискримінаційного вибору роботодавців, соціальні стереотипи яких є підгрунтям їх економічних рішень у процесі найму робочої сили. Проте слід зауважити, що автор цієї моделі визначає факт дискримінації лише за етнічною та демографічною ознаками.

Ураховуючи наведене вище, вважаємо, що для ліквідації негативних суперечностей слід забезпечувати взаємодію ринку праці та ринку освітніх послуг шляхом вивчення їх 
стану та розроблення короткострокових прогнозів щодо можливостей працевлаштування. Для цього слід активізувати участь вищих навчальних закладів у розв'язанні проблеми подолання дисбалансу ринку освітніх послуг та ринку праці, забезпечення економіки країни висококваліфікованою робочою силою. Як показує світовий досвід, маркетингові служби вищих навчальних закладів, які вивчають потреби ринку праці, вимоги роботодавців, мають стати невід'ємним складником структури управління вищого навчального закладу.

Задля розв'язання проблеми взаємозв'язку ринку праці й ринку освітніх послуг потрібно: розробити нові підходи щодо механізму взаємодії вищого навчального закладу та підприємств із питань забезпечення підготовки кадрів, зокрема і формуванням практичних умінь і навичок під час проходження навчальної i виробничої практик; створити нормативно-правову базу відповідальності роботодавців за використання кваліфікованої робочої сили; едосконалити механізм працевлаштування випускників вищих навчальних закладів із пристосуванням певного організаційно-розпорядчого механізму до умов ринкової економіки в суспільстві.

\section{Література}

1. Закон України «Про формування та розміщення державного замовлення на підготовку фахівців, наукових, науково-педагогічних та робітничих кадрів, підвищення кваліфікації та перепідготовку кадрів» від 20.11.2012 р. № 5499-VI [Електронний ресурс]. Режим доступу: http://zakon4.rada.gov.ua/laws/show/5499-17. 2. Мартякова Е. В. Инновационные технологии в системе гармонизации рынков труда и образования/ Е. В. Мартякова // Маркетинг і менеджмент інновацій. - 2010. - № 2. - С. 160-169. 3. Петрова Т. Ринок освітніх послуг і ринок праці : проблеми взаємозв'язку та взаємодії / Т. Петрова // Україна : аспекти пр. 2006. - № 34. - С. 26-30. 4. Пилипенко Г. М. Суперечності взаємодії ринків освітніх послуг та праці в Україні/ Г. М. Пилипенко, Ю. Пилипенко // Матеріали Всеукраїнської науково-практичної конференції ДВНЗ «Національний гірничий університет» м. Дніпропетровськ (11-12 квітня 2013 р.). Дніпропетровськ: ДВНЗ «Національний гірничий університет».5. Савченко Г. О. Шляхи підвищення ефективності взаємодії та взаємозв'язку ринків праці та освітніх послуг / Г. О. Савченко, Т. П. Збрицька // Вісник соціально-економічних досліджень. - 2012. - Вип. 1 (44). - С. 4-9. 6. Becker G. The Economics of Discrimination. Chicago, 19711971 // Цит. за : Р. Эренберг, Р. Смит. Современная экономика тр. - Москва : Просвещение, 2006. - С. 463-469. 